\title{
Research Article \\ Study on the Influence of Various Rainfall Types on the Stability of High and Steep Slopes
}

\author{
Jin Qian, ${ }^{1}$ Ding Sun, ${ }^{2}$ Guodong Li $\mathbb{D}^{1},{ }^{1}$ and Yue Wu $\mathbb{D}^{1}$ \\ ${ }^{1}$ Changchun University of Architecture and Civil Engineering, Changchun 130000, China \\ ${ }^{2}$ Northwest A\&F University, Yangling 712100, China \\ Correspondence should be addressed to Guodong Li; 36727642@qq.com and Yue Wu; 25023014@qq.com
}

Received 23 July 2021; Accepted 25 October 2021; Published 7 December 2021

Academic Editor: Xudong Zhang

Copyright (c) 2021 Jin Qian et al. This is an open access article distributed under the Creative Commons Attribution License, which permits unrestricted use, distribution, and reproduction in any medium, provided the original work is properly cited.

Taking the high and steep slope of a ski resort as the background, in order to ensure the structural safety of the slope in the subsequent complex rainfall environment, the calculation principle of unsaturated soil slope stability is summarized, and the parameter interaction analysis is proposed. The numerical simulation method is used to study the influence of various rainfall types on slope stability; combined with a multiparameter combination, the slope stability is analyzed. The results show that different types of rainfall have a significant impact on the safety factor of the slope, the safety factor of the slope under the front rainfall type is the smallest, the minimum value is 1.38 , and the front rainfall mostly occurs in the late summer, so it is necessary to avoid construction in the late summer or do a good job of safety monitoring in the late summer. Through setting monitoring points, it is found that the pore water pressure of the three positions from small to large is in the order of slope toe<slope middle<slope top, and the pore water pressure at the slope toe is basically $0 \mathrm{kPa}$. At this time, the matric suction at the slope toe is the minimum, so the protection should be strengthened. In the combination analysis of the four parameters, the direct effect and coupling effect of $\mathrm{C} 15$ are at a small level, which indicates that when the four parameters fluctuate together, the mutual coupling is not the effect of a single parameter, which provides a theoretical reference for the follow-up related research.

\section{Introduction}

With the development of the national economy, a large number of railways, highways, water conservancies, mines, towns, and other facilities are built, especially in the construction of hills and mountainous areas. In human engineering activities, more and more slopes are excavated and filled, and the slope height is increasing [1-4]. Due to the complex geological conditions in China and with the increasing scale of human transformation of nature, engineering disasters caused by improper design and construction are frequent. In addition to the inherent factors such as geology and geomorphology, the complex natural environment such as rainfall, freeze-thaw cycle, and earthquake will have an inestimable impact on the slope stability.

Domestic and foreign scholars have studied slope stability in complex environments by means of statistical analysis, field tests, theoretical analysis, and numerical simulation and achieved a series of research results [5-8].

Tang et al. [9] studied parameters of the soil-water characteristic curve with a homogeneous slope as an example $\alpha$ and $n$ on slope stability. Lin et al. [10] obtained the conclusion that the low rainfall intensity and long duration rainfall will increase the pore water pressure of deep soil, resulting in sliding failure and large-scale landslide. Yang et al. [11, 12] studied the influence order of heavy rain, rainstorm, and torrential rain on the pore water pressure change of the slope with a weak interlayer and the variation law of the safety factor and plastic zone under different rainfall conditions. Zhou et al. [13] showed that the safety factor of the slope decreased continuously in the process of rainfall infiltration, but after the rain stopped, the safety factor of the slope decreased gradually. Based on the saturated-unsaturated seepage theory and strength reduction method, Xu et al. [14] analyzed 
the soil slope, which showed that with the increase of rainfall intensity, the change range of the safety factor was larger. Wang et al. [15] combined with the saturated-unsaturated seepage theory studied the change law of the slope seepage field under different rainfall types. In the above studies, the mechanical parameters of soil material are set as fixed values, and the spatial variability of soil material is not considered.

Luo et al. [16] took 1022 landslides in the National Geopark induced by the Jiuzhaigou earthquake in 2017 as sample data and cross-validated the spatial prediction accuracy of the initial model by using the Bayesian probability method and generalized additive statistical model. Ping et al. [17] took a natural loess slope in Jingyang as the research object, carried out artificially simulated rainfall experiments of the large loess slope under different rainfall intensities, and summarized the water infiltration law and deformation failure mode of the loess slope. Liang et al. $[18,19]$ used $3 \mathrm{D}$ printing technology to make plant rhizomes, studied the influence of slope height on vegetation to improve slope stability under earthquake action, and found that vegetation is a very effective method to reduce earthquake sliding for slopes with smaller height (such as low height embankment along traffic infrastructure). Chen et al. [20] used the integral limit equilibrium variational method to give a detailed theoretical derivation and solution process, obtained the expressions of critical slip surface function and stress function, and gave the solution method of the safety factor. Chen [21] vigorously developed the limit analysis method and successfully applied it to the stability analysis of saturated homogeneous soil. Based on the limit equilibrium method, Han et al. [22] proposed a three-dimensional loading stability analysis method for the anisotropic heterogeneous slope, which can be regarded as the improvement and expansion of the solution, and studied the influence of the friction angle, anisotropic factor, heterogeneous factor, slope angle, width depth ratio, top load, and other factors on slope stability. Cai et al. [23], based on the principle of saturatedunsaturated seepage, taking the low highway slope in Yunnan Province as the research object, calculated and analyzed the slope stability and reliability under different rainfall intensities by using GeoStudio finite element software.

It is not difficult to find that at present, the research on slope stability at home and abroad is mostly on common slopes [24-27], but the study on the stability of high and steep slopes is still less, especially in the complex rainfall environment. In view of this, this paper takes a ski resort as the engineering background and uses GeoStudio finite element analysis software to study the influence of various rainfall types (forward type, center front type, back front type, and average type) on the stability of high and steep slopes. Meanwhile, the best coupling combination is proposed by using the method of parameter combination analysis, and the internal mechanism of the influence of rainfall infiltration on slope stability is analyzed, providing guidance and guarantee for subsequent construction and operation.

\section{Calculation Principle of Slope Stability}

2.1. Unsaturated Fluid-Structure Interaction and Variance Theory. Rainfall infiltration is a typical unsaturated fluidsolid coupling process. The incompleteness of soil makes the infiltration water flow along the pores and produces seepage water pressure, which forms the strain field of soil structure in the form of seepage volume force and then forms the changes of displacement and volume strain. Rainfall infiltration affects the permeability coefficient and seepage field of soil. It can be seen from the basic principle of hydraulics [28] that the seepage volume force of the continuous porous rock and soil medium is in a positive proportion to the hydraulic gradient, which can be expressed as

$$
\begin{aligned}
& {\left[\begin{array}{l}
f_{x} \\
f_{y} \\
f_{z}
\end{array}\right]=\left[\begin{array}{ll}
-\gamma_{\mathrm{w}} \frac{\partial h}{\partial x}-\gamma_{\mathrm{w}} \frac{\partial h}{\partial y} & -\gamma_{\mathrm{w}} \frac{\partial h}{\partial z}
\end{array}\right]^{T}=\left[\begin{array}{l}
-\gamma_{\mathrm{w}} J_{x} \\
-\gamma_{\mathrm{w}} J_{y} \\
-\gamma_{\mathrm{w}} J_{z}
\end{array}\right],} \\
& \left\{\begin{array}{l}
f=\sqrt{f_{x}^{2}+f_{y}^{2}+f_{z}^{2}}, \\
\theta_{1}=\arctan f_{x} / f, \theta_{2}=\arctan f_{y} / f, \theta_{3}=\arctan f_{z} / f,
\end{array}\right.
\end{aligned}
$$

where $\gamma_{\mathrm{w}}$ is a constant determined by soil structure and fluid properties; $h$ is the total rainfall head; $f$ is the seepage volume force of rainfall infiltration; $f_{x}, f_{y}$, and $f_{z}$ are the components of $f$ in $x, y$, and $z$ directions, respectively; $\theta_{1}, \theta_{2}$, and $\theta_{3}$ are the angle between the seepage volume force and the component value; and $J_{x}, J_{y}$, and $J_{z}$ are the hydraulic gradients of volume elements in $x, y$, and $z$ directions, respectively.

In the numerical analysis of geotechnical engineering, when the finite element method is used to solve the stress field, the seepage volume force of the element can be transformed into the equivalent nodal load through formulas (2) and (3) below:

$$
\begin{array}{r}
F=\int_{\Omega} N^{T}\left[\begin{array}{lll}
f_{x} & f_{y} & f_{z}
\end{array}\right]^{T} d x d y d z, \\
\Delta F=\int_{\Omega} N^{T}\left[\begin{array}{lll}
f_{x} & f_{y} & f_{z}
\end{array}\right]^{T} d x d y d z,
\end{array}
$$

where $\Omega$ is the infiltration volume; $N$ is the shape function matrix of the slope element; and $F$ and $\Delta F$ are the equivalent nodal forces produced by the seepage volume force and increment value, respectively.

In the seepage stress coupling analysis, the empirical relationship between the porosity and the permeability coefficient is adopted.

$$
k\left(\delta_{i j}\right)=k\left[\frac{n\left(1-n_{0}\right)}{n_{0}(1-n)}\right]^{3},
$$

where $n_{0}$ and $n$ are the initial state of slope soil and the 
porosity after rainfall infiltration, respectively; and $k$ and $k\left(\delta_{i j}\right)$ are the permeability coefficient before and after infiltration.

Seepage volume force and other external loads cause the change of the soil stress field and consolidation deformation and the change of the void ratio and porosity, then affect the permeability coefficient, and finally cause the change of the seepage field [29].

The two-dimensional steady seepage field under the action of the stress field can be characterized as

$$
\begin{cases}\frac{\partial}{\partial x}\left[k\left(\delta_{i j}\right)\right] \frac{\partial H}{\partial x}+\frac{\partial}{\partial y} k\left(\delta_{i j}\right) \frac{\partial H}{\partial y}=0, & (x, y) \in \Omega, \\ H(x, y)=H_{1}(x, y), & (x, y) \in \Gamma_{1}, \\ {\left[k\left(\delta_{i j}\right)\right] \frac{\partial H}{\partial n_{2}}=q(x, y),} & (x, y) \in \Gamma_{2}, \\ H(x, y)=y,\left[k\left(\delta_{i j}\right)\right] \frac{\partial H}{\partial n_{3}}=0, & (x, y) \in \Gamma_{3},\end{cases}
$$

where $\left[k\left(\delta_{i j}\right)\right]$ is the element seepage coefficient matrix formed by nodes; $H$ is the total head; $H_{1}$ is a known function of $\Gamma_{1} ; n_{2}$ and $n_{3}$ are the normal directions of $\Gamma_{2}$ and $\Gamma_{3}$, respectively; $\Gamma_{1}$ is the water head boundary; $\Gamma_{2}$ is the flow boundary; $\Gamma_{3}$ is the boundary of infiltration basin; and $q$ is the unit seepage.

The relationship between the permeability coefficient, saturation, and matric suction can be expressed as

$$
K_{\mathrm{w}}=\frac{a_{\mathrm{w}} K_{\mathrm{ws}}}{a_{\mathrm{w}}+\left(b_{\mathrm{w}} u_{\mathrm{a}}-b_{\mathrm{w}} u_{\mathrm{b}}\right)^{c_{\mathrm{w}}}},
$$

where $K_{\mathrm{w}}$ is the current permeability coefficient; $K_{\mathrm{ws}}$ is the saturated permeability coefficient of soil; $u_{\mathrm{a}}$ and $u_{\mathrm{b}}$ are the air pressure and water pressure in the slope soil, where $u_{\mathrm{a}}$ $=0$ and $u_{\mathrm{b}}=0$; and $a_{\mathrm{w}}, b_{\mathrm{w}}$, and $c_{\mathrm{w}}$ are the material coefficients.

$$
S_{\mathrm{r}}=\frac{S_{\mathrm{i}}+a_{\mathrm{s}}\left(S_{\mathrm{n}}-S_{\mathrm{i}}\right)}{\left[a_{\mathrm{s}}+\left(b_{\mathrm{s}} u_{\mathrm{a}}-b_{\mathrm{s}} u_{\mathrm{w}}\right)^{c_{\mathrm{s}}}\right]},
$$

where $S_{\mathrm{r}}$ and $S_{\mathrm{i}}$ are the saturation and residual saturation, respectively, where $S_{\mathrm{i}}=0.08$; and $S_{\mathrm{n}}$ is the maximum saturation, where $S_{\mathrm{n}}=1$.

Under the action of the seepage field, the function characterization model of the stress field is as follows:

$$
\begin{cases}K \times \Delta \delta=\Delta F+\Delta F_{\mathrm{s}}, & (x, y) \in \Omega, \\ \delta=\delta_{0}, & (x, y) \in S_{\mathrm{u}}, \\ \delta_{i j} n_{j}=T_{\mathrm{i}}, & (x, y) \in S_{\delta},\end{cases}
$$

where $T_{\mathrm{i}}$ is the surface force distribution on the $S_{\mathrm{u}}$ boundary; $K$ is the slope stiffness matrix; $\Delta F$ is the node load increment caused by the external load; $\Delta F_{\mathrm{s}}$ is the node load increment caused by seepage volume force; $\Delta \delta$ is the displacement change; $\delta$ and $\delta_{0}$ are the node displacement and initial node displacement; and $S_{\mathrm{u}}$ and $S_{\delta}$ are the displacement and stress boundary, respectively.

It can be seen from equations (7) and (8) that the matrix function expression of seepage stress coupling is as follows:

$$
\left\{\begin{array}{l}
K \Delta \delta=\Delta F+\Delta F_{s} \\
K \Delta \delta H+f=0 \\
k=k\left(\delta_{i j}\right)
\end{array}\right.
$$

where $f$ is the water distribution of the rainfall infiltration field.

2.2. Stability Theory of the Unsaturated Soil Slope. Landslide refers to the phenomenon that the slope loses its original stable state and moves down the slope along a sliding surface as a whole. Landslide is mainly caused by the shear stress on one side of the soil (landslide surface) exceeding its shear strength. The slope soil under the complex rainfall environment is mostly unsaturated soil. For unsaturated soil, the main reason for slope instability is the decrease or loss of soil matric suction caused by rainfall. Therefore, the research on the mechanism between unsaturated soil shear strength and matric suction is of great significance.

The shear strength formula of saturated soil was first proposed by Coulomb:

$$
\tau_{\mathrm{f}}=c+\sigma \tan \phi
$$

where $\tau_{\mathrm{f}}$ is the shear strength; $c$ is the cohesive force; $\sigma$ is the normal stress; and $\phi$ is the internal friction angle.

On the basis of the Mohr-Coulomb shear strength formula, the concept of matric suction is introduced and different shear strength formulas of unsaturated soil are established.

The shear strength formula of unsaturated soil proposed by Bishop [30] in 1960 can be expressed as follows:

$$
\tau_{\mathrm{f}}=c^{\prime}+\left[\sigma-u_{\mathrm{a}}+\chi\left(u_{\mathrm{a}}-u_{\mathrm{w}}\right)\right] \tan \phi^{\prime}
$$

where $c^{\prime}$ is the effective cohesion; $u_{\mathrm{a}}$ is the pore gas pressure; $u_{\mathrm{w}}$ is the pore water pressure; $\chi$ is a parameter related to the type and saturation of soil; and $\phi^{\prime}$ is the effective internal friction angle. Although the value of $\chi$ is related to the type and saturation of soil, its physical meaning is not clear and cannot be obtained simply by experiment or theory, so it is difficult to popularize it in practical engineering.

In 1978, Fredlund et al. [31] put forward the shear strength formula of unsaturated soil with normal stress and suction as variables.

$$
\tau_{\mathrm{f}}=c^{\prime}+\left(\sigma-u_{\mathrm{a}}\right) \tan \phi^{\prime}+\left(u_{\mathrm{a}}-u_{\mathrm{w}}\right) \tan \phi^{b},
$$

where $\tan \phi^{b}$ is the rate at which shear strength increases with suction $\left(u_{\mathrm{a}}-u_{\mathrm{w}}\right)$.

Comparing equation (11) with equation (12), it can be found that equation (11) simply regards matric suction as the increase of effective stress, while equation (12) considers 
the influence of matric suction on the shear strength of unsaturated soil separately, which is more accurate than equation (12). However, $\phi^{b}$ and $\chi$ cannot be measured by a simple test, and they are difficult to be applied to practical engineering.

Vanapalli et al. $[32,33]$ put forward the empirical model of shear strength of unsaturated soil, innovatively connecting $\phi^{b}$ with the change of water content in soil, in which the relationship between $\phi^{b}$ and water content in soil can be expressed as follows:

$$
\tan \phi^{b}=\left(\frac{\theta-\theta_{\mathrm{r}}}{\theta_{\mathrm{s}}-\theta_{\mathrm{r}}}\right) \tan \phi^{\prime}
$$

where $\theta$ is the volume moisture content; $\theta_{\mathrm{r}}$ is the residual volume moisture content; and $\theta_{\mathrm{s}}$ is the saturated volumetric moisture content, and the further shear strength of unsaturated soil can be expressed as

$$
\tau_{\mathrm{f}}=c^{\prime}+\left(\sigma-u_{\mathrm{a}}\right) \tan \phi^{\prime}+\left(u_{\mathrm{a}}-u_{\mathrm{w}}\right)\left[\left(\frac{\theta-\theta_{\mathrm{r}}}{\theta_{\mathrm{s}}-\theta_{\mathrm{r}}}\right) \tan \phi^{\prime}\right] .
$$

The shear strength formula of unsaturated soil is established by formula (14), and $\phi^{b}$ can be determined by the characteristic curve of soil and water, which can be widely used in practical engineering. However, the study of slope stability involves not only the design and construction of the existing subgrade slope but also an important research direction of the stability of the natural slope. How to prevent the landslide and how to warn early the quantity of landslide earthwork are inevitable problems in actual engineering. At present, the early warning of the slope is mainly through two methods, namely, field detection and finite element model prediction.

Based on the study of the soil-water characteristic curve, van Genuchten obtained the relationship between unsaturated soil-water content and matric suction in the form of power function (V-G model):

$$
F(\psi)=\frac{\theta-\theta_{\mathrm{r}}}{\theta_{\mathrm{s}}-\theta_{\mathrm{r}}}=\frac{1}{\left[1+(\psi / a)^{b}\right]^{(1-(1 / b))}}
$$

where $\psi$ is the matric suction; and $a$ and $b$ are the fitting parameters. By substituting the $\mathrm{V}-\mathrm{G}$ model into equation (14), the following results are obtained:

$$
\tau_{\mathrm{f}}=c^{\prime}+\left(\sigma-u_{\mathrm{a}}\right) \tan \phi^{\prime}+\left(u_{\mathrm{a}}-u_{\mathrm{w}}\right) \frac{1}{\left[1+(\psi / a)^{b}\right]^{(1-(1 / b))}} \tan \phi^{\prime} .
$$

The GeoStudio finite element analysis software used in this paper is based on the V-G model described in equation (16).
2.3. Analysis Principle of Influencing Factors. The soil saturated permeability coefficient, rainfall intensity, MohrCoulomb parameters of material properties, and friction angle are the key internal and external factors to determine the stability of the soil slope. In order to analyze the influence of the above four parameters on slope stability, it is necessary to analyze their interaction. Finally, the quantization degree of the output parameters under the input parameters and the interaction between the parameters are realized by using the effect of the variance of the input parameters on the variance of the output results [34]. Taking the pore pressure, saturation, safety factor, and effective stress of the slope model under rainfall infiltration as output parameters and taking the saturated permeability coefficient of soil, rainfall intensity, MohrCoulomb parameters of material properties, and friction angle as input parameters, the global quantitative analysis is carried out. The parameter is defined as the input parameter of the model $y=y\left(x_{1}, x_{2}, \cdots, x_{m}\right)$, and the relationship between the input parameter $I$ and the output parameter can be defined as

$$
d_{i}\left(x_{i}\right)=\frac{\left[y\left(x_{1}, x_{2}, \cdots, x_{i-1}, x_{i}+\Delta, x_{i+1}, \cdots, x_{k}\right)-y(x)\right]}{\Delta},
$$

where $d_{i}\left(x_{i}\right)$ is the influence degree of the change of parameter $x_{i}$ on the output value $d_{i}$, that is, the sensitivity of the output value to the change of the parameter, where $x_{i}$ is the output parameter (saturated permeability coefficient of soil, rainfall intensity, Mohr-Coulomb parameter of material properties, and friction angle); $y$ is the output parameter (pore pressure, saturation, safety factor, and effective stress); and $\Delta$ is the difference before and after the change of the same input parameter.

The model of $k$ input parameters is established, $i=1,2$, $\cdots, k$, and the input parameters are valued at $p$ levels. Multiple sampling is used to replace repeated sampling, and the mean value of output parameters determined by multiple sampling calculation is used to represent the direct effect of input parameters on output, and the standard deviation of statistics is used to represent the interaction between input parameters.

\section{Engineering Examples}

3.1. Project Overview. This paper takes the high and steep slope of a ski resort as an example. The slope height is $130 \mathrm{~m}$, and the longitudinal length is $350 \mathrm{~m}$. The slope is divided into two steps, the first step is the starting area, and the slope is 0.5. The slope of the second step is the auxiliary slide with a slope of 0.26 . According to the slope classification, the slope in the starting area is high and steep. The water level elevation on the left side of the slope is $50 \mathrm{~m}$, and that on the right side is $40 \mathrm{~m}$. The schematic diagram of the slope is shown in Figure 1. Taking the high and steep slope in the starting area as the research object, this paper studies the influence of various rainfall conditions on the stability of high and steep slopes. 


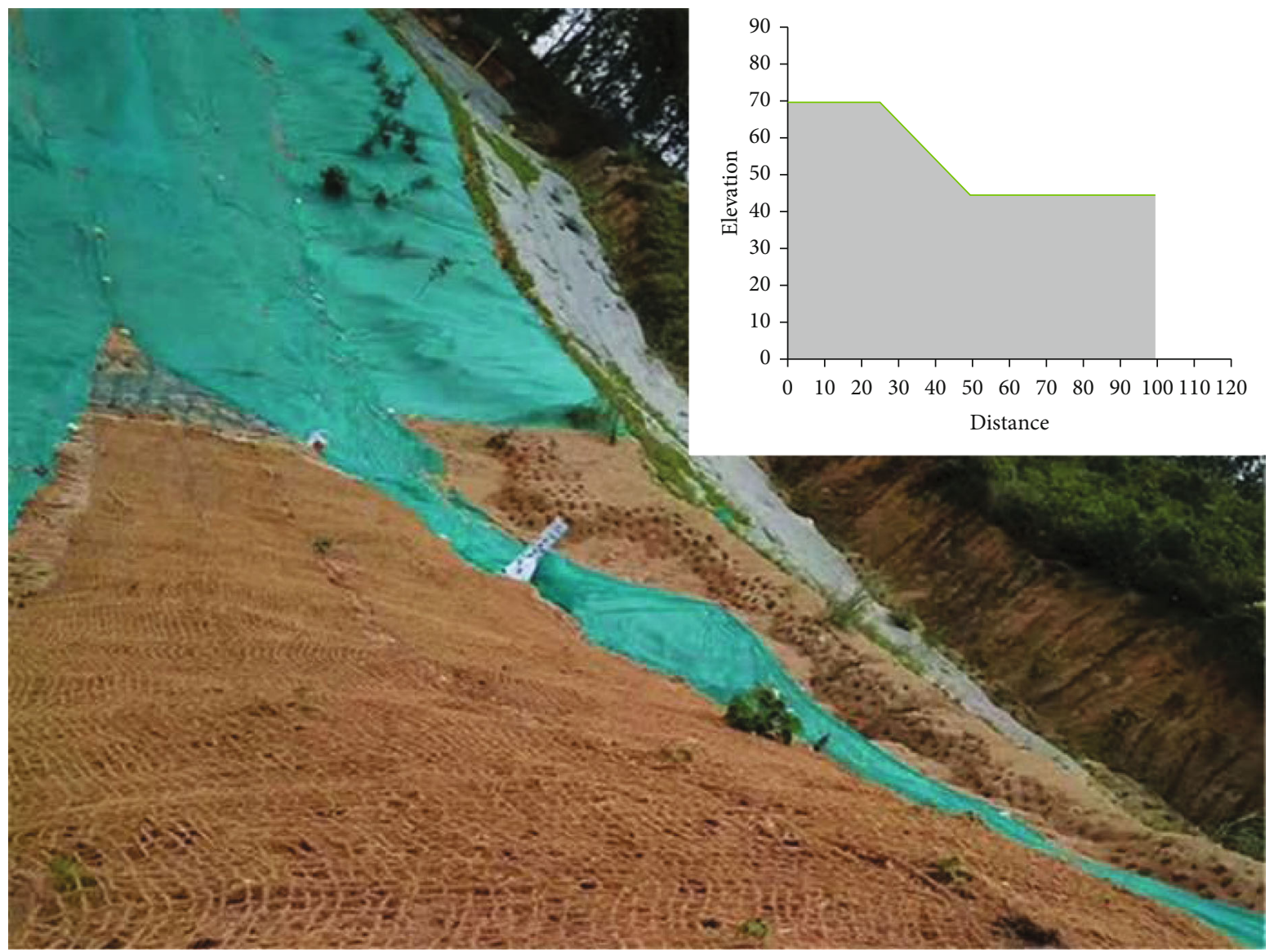

FIgURE 1: Schematic diagram of the slope.

TABLE 1: Mechanical parameters of soil.

\begin{tabular}{lcccccc}
\hline $\begin{array}{l}\text { Soil } \\
\text { layer }\end{array}$ & $\begin{array}{c}\text { Unit weight }(\mathrm{kN} / \\
\left.\mathrm{m}^{3}\right)\end{array}$ & $\begin{array}{c}\text { Permeability coefficient } \\
(\mathrm{mm} / \mathrm{h})\end{array}$ & $\begin{array}{c}\text { Cohesion } \\
(\mathrm{kPa})\end{array}$ & $\begin{array}{c}\text { Internal friction } \\
\text { angle }\left(^{\circ}\right)\end{array}$ & $\begin{array}{c}\text { Poisson's } \\
\text { ratio }\end{array}$ & $\begin{array}{c}\text { Saturated volume water } \\
\text { content } \theta_{\mathrm{s}}\end{array}$ \\
\hline Siltstone & 18 & 20 & 20 & 28 & 0.3 & 0.45 \\
\hline
\end{tabular}

\subsection{Numerical Simulation}

3.2.1. Model Parameters. According to the geological exploration report, the soil layer of the first step slope is mainly completely weathered siltstone, and its corresponding physical and mechanical parameters are shown in Table 1 . The soil-water characteristic curve adopts the V-G model: $a=$ $20 \mathrm{kPa}, n=2, m=1-(1 / n)=0.5, \theta_{\mathrm{s}}=0.45$, and $\theta_{\mathrm{r}}=0.3$, and the soil-water characteristic curve and function permeability curve are shown in Figure 2.

3.2.2. Rainfall Parameters. The project site belongs to the warm temperate semihumid monsoon climate zone, with significant continental monsoon climate characteristics and four distinct seasons. It is cold and dry in winter, with northwest wind prevailing. In summer, the rainfall is concentrated and southeast wind prevails. It is dry and windy in spring and cool and rainless in autumn. In addition, due to the influence of topography, precipitation is unevenly distributed not only in four seasons but also in different places. The annual difference between the rainy area and the less rainy area is $100-200 \mathrm{~mm}$. Spring precipitation accounts for $5 \%-15 \%$ of annual precipitation. Summer precipitation accounts for $70 \%-80 \%$ of annual precipitation. The precipitation in autumn accounts for $11 \%-15 \%$ of annual precipitation, slightly more than that in spring. Winter precipitation is very little, accounting for only $1 \%-4 \%$ of annual precipitation. The average annual precipitation of the project site from 1956 to 2008 is $559 \mathrm{~mm}$. According to the rainfall grade specified by the meteorological department (Table 2), combined with the local rainfall, the rainfall parameters are defined as four types of rainfall [35], namely, forward type, center type, rear type, and average type. The duration of rainfall is 7 days. Considering the influence of rainfall infiltration, the working conditions of 7 days after rainfall are also included in the time range. The rainfall process is shown in Figure 3.

\section{Result Analysis}

4.1. Natural Slope Stability Analysis. In order to better analyze the influence of different rainfall types on slope stability, 


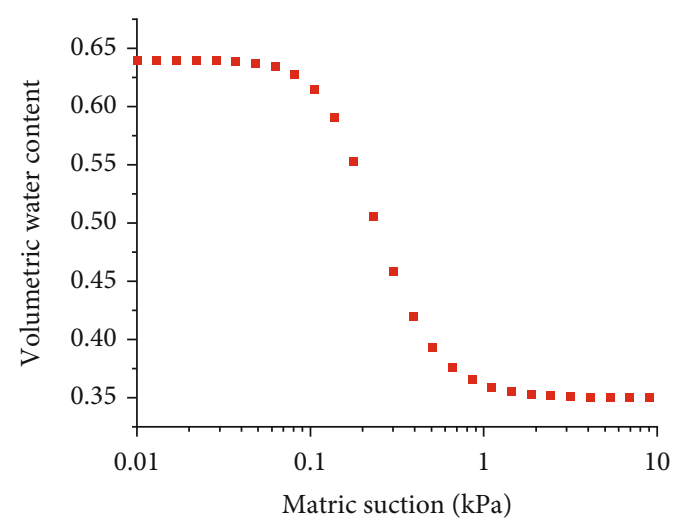

Volumetric water content

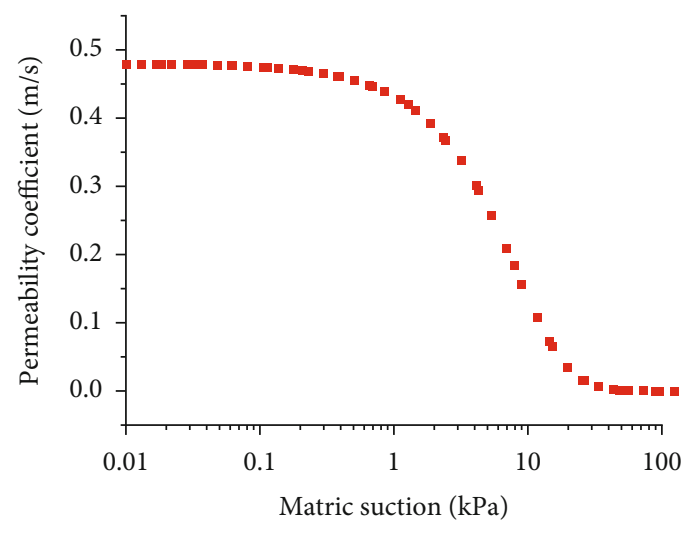

Permeability coefficient

Figure 2: Soil-water characteristic curve.

TABLE 2: Rainfall grade.

\begin{tabular}{llcccc}
\hline Light rain & Moderate rain & Heavy rain & Rainstorm & Downpour & Torrential rain \\
\hline$<10 \mathrm{~mm} /$ day & $10 \sim 25 \mathrm{~mm} /$ day & $25 \sim 50 \mathrm{~mm} /$ day & $50 \sim 100 \mathrm{~mm} /$ day & $100 \sim 250 \mathrm{~mm} /$ day & $>250 \mathrm{~mm} /$ day \\
\hline
\end{tabular}

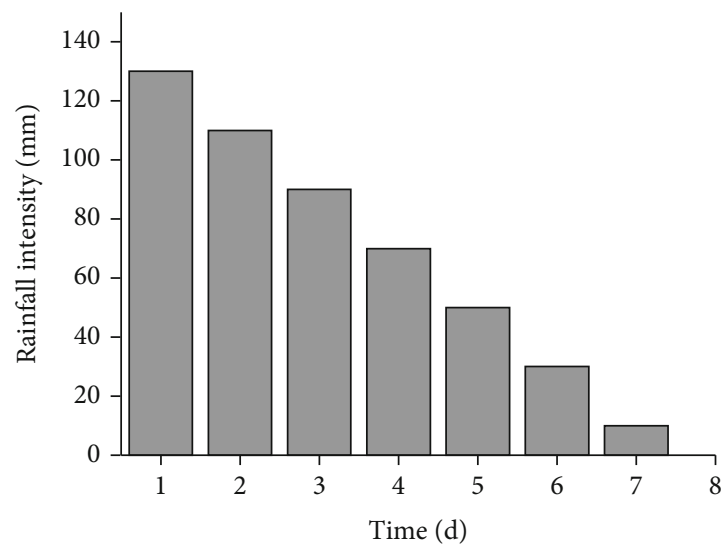

(a) Forward type (referred to as F)

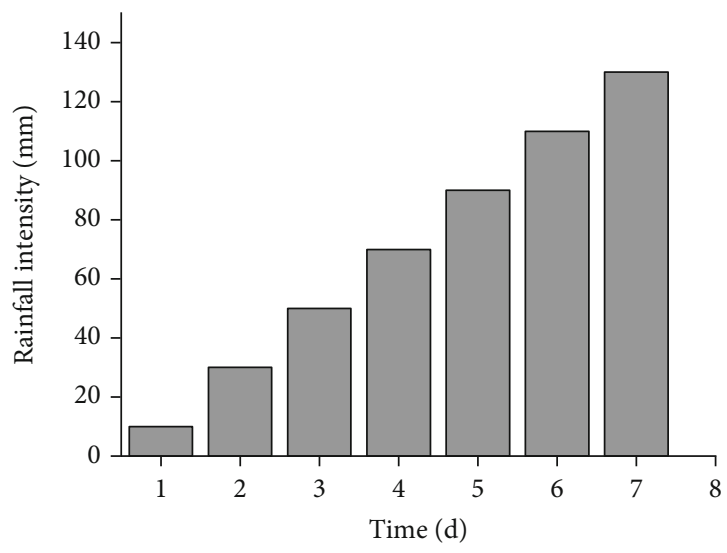

(c) Back forward type (referred to as B)

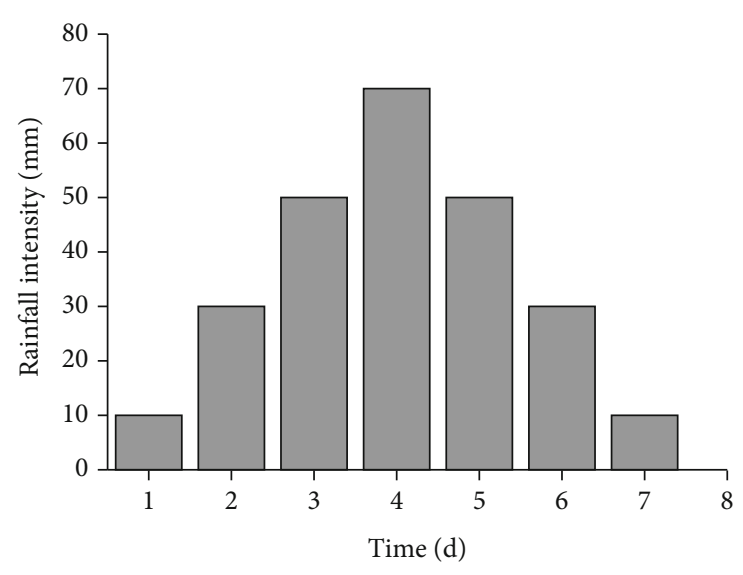

(b) Center type (referred to as C)

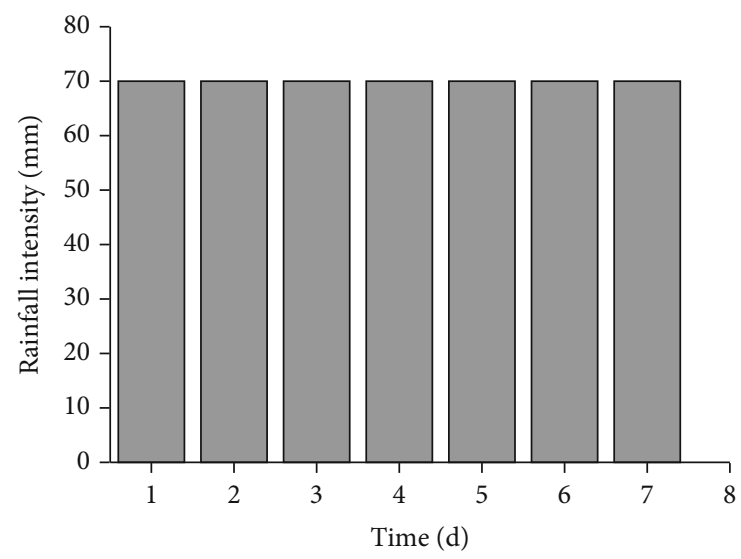

(d) Average type (referred to as A)

Figure 3: Rainfall types.

the stability of the natural slope is analyzed firstly. The cloud diagram of pore water pressure under the natural state is shown in Figure 4. It can be seen that the saturated soil is below the initial water level, the pore water pressure is positive, and the unsaturated soil is above the initial water level. Under the action of capillary water, the capillary water rises, 


\begin{tabular}{|l|}
$\square-250--200 \mathrm{kPa}$ \\
$\square-200--150 \mathrm{kPa}$ \\
$\square-150--100 \mathrm{kPa}$ \\
$\square-100--50 \mathrm{kPa}$ \\
$\square-50-0 \mathrm{kPa}$ \\
$\square 0-50 \mathrm{kPa}$ \\
$\square 50-100 \mathrm{kPa}$ \\
$\square 100-150 \mathrm{kPa}$ \\
$\square 150-200 \mathrm{kPa}$ \\
$\square 200-250 \mathrm{kPa}$ \\
$\square 250-300 \mathrm{kPa}$ \\
$\square 300-350 \mathrm{kPa}$ \\
$\square 350-400 \mathrm{kPa}$ \\
$\square 400-450 \mathrm{kPa}$ \\
$\square 450-500 \mathrm{kPa}$ \\
\hline
\end{tabular}

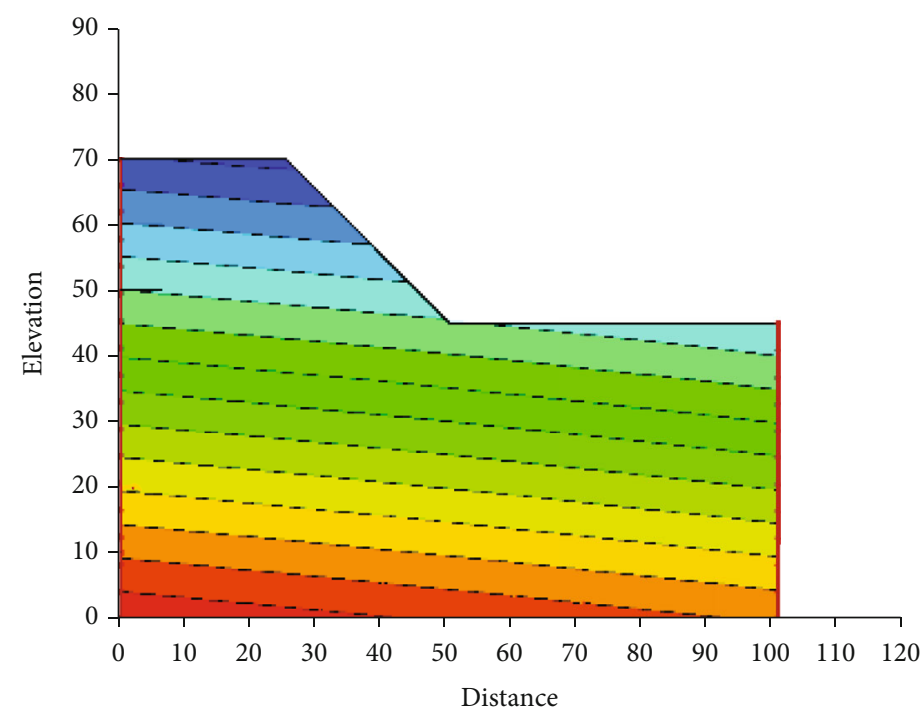

Figure 4: Pore water pressure in the natural state.

and the pore water pressure is negative. It can be seen from the equation that when the pore water pressure is negative, the matric suction is greater than zero, and the shear strength of the soil is enhanced. At this time, the initial water level is at the foot of the slope, and because the safety factor of the slope is 1.5 , the slope can be considered to be stable.

\subsection{Slope Stability Analysis under Various Rainfall Conditions}

4.2.1. Safety Factor. The influence of rainfall infiltration on slope stability has been a key issue in geotechnical engineering. The safety factor is a parameter which can reflect the slope stability directly. Figure 5 shows the slope safety coefficient under different rainfall types. It can be seen from Figure 5 that in the rainfall stage, the safety coefficient of the slope decreases with the continuous rainfall and the change range is more intense. After the rain stops on the 7 th day, the rainwater will continue to infiltrate, the water level will gradually decrease, and the change range of the safety coefficient is slow and gradually stable. In addition, the law of the change of the safety coefficient under different rainfall types can be seen from the comparison of the rainfall stage: forward type $<$ average type $<$ center front type $<$ back front type, which is because the rainfall of the forward type is much larger than those of the other three types in the initial stage of rainfall, and the soil mass of the slope can reach the saturation state in a short time, which leads to the rapid decrease of matric suction and slope stability, The macroperformance is that the safety coefficient is reduced rapidly. The theory infers that the variation law of the safety coefficient of the average type and center front type is also verified. The safety coefficient of the first three days of the front-type rainfall is always greater than that of the average rainfall condition. However, with the increasing rainfall of the center front type, the gap between the two is smaller and smaller. On the

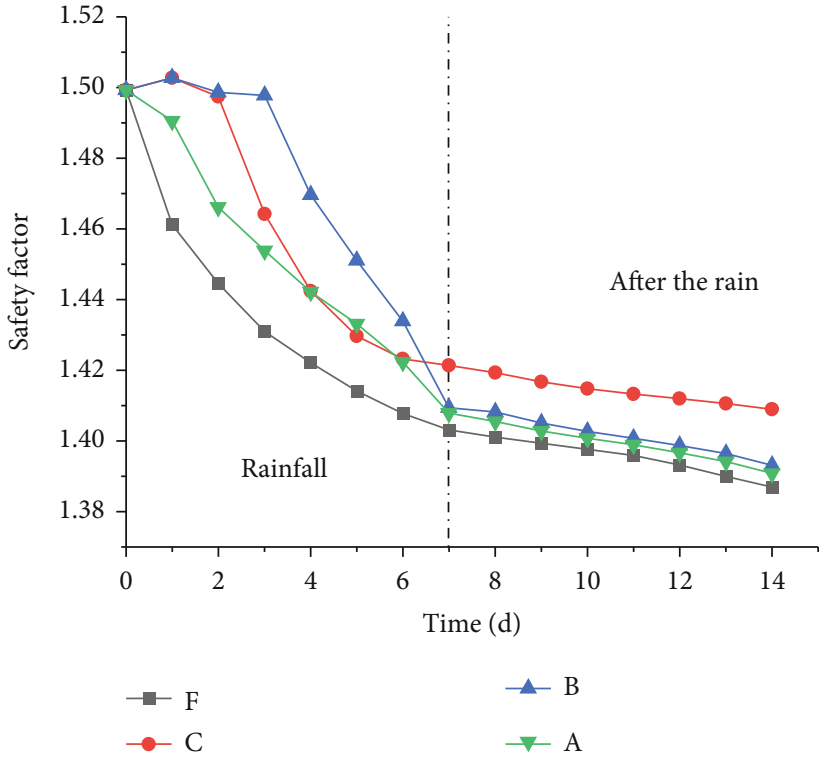

Figure 5: Change diagram of the safety factor.

fourth day, the rainfall intensity of the center front type and the average type is $70 \mathrm{~mm}$. At this time, the safety coefficient of the center front type is almost equal to that of the average type. In the next three days, with the decrease of the rainfall intensity of the center front type, the safety coefficient of the front-type rainfall condition gradually exceeds that of the average one. The whole change of the safety factor can be divided into two stages, the first stage is the sharp decline stage, and the four rainfall modes show the same law. With the rainfall no longer changing, the safety coefficient is gradually stable. Although the total rainfall is consistent, the final safety factor decreases in the same trend, but the change of the safety factor caused by different rainfall types in the process of rainfall is different, which is also the significance of this study. 


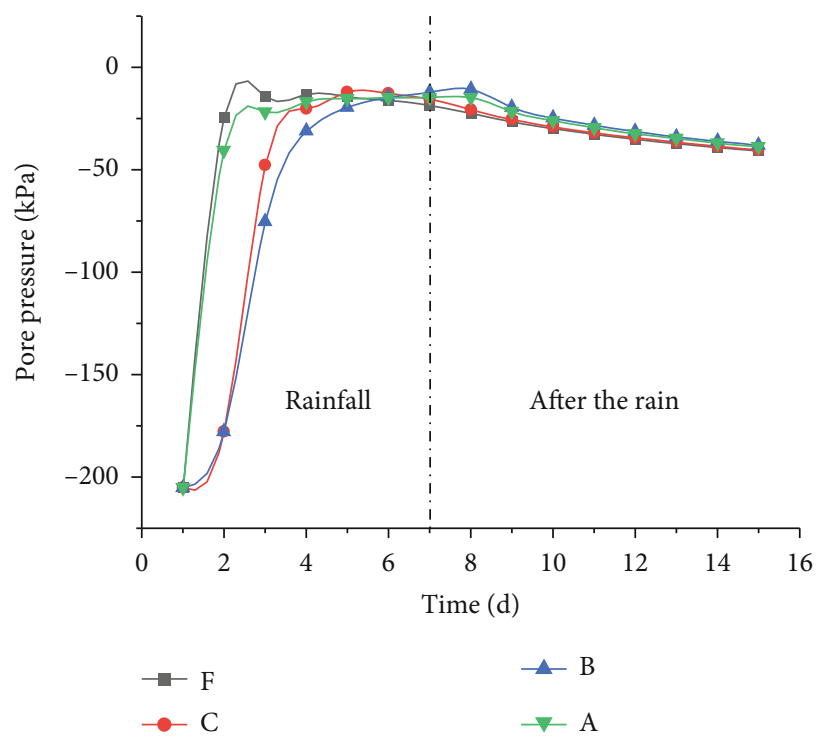

(a) Pore pressure at the top of the slope

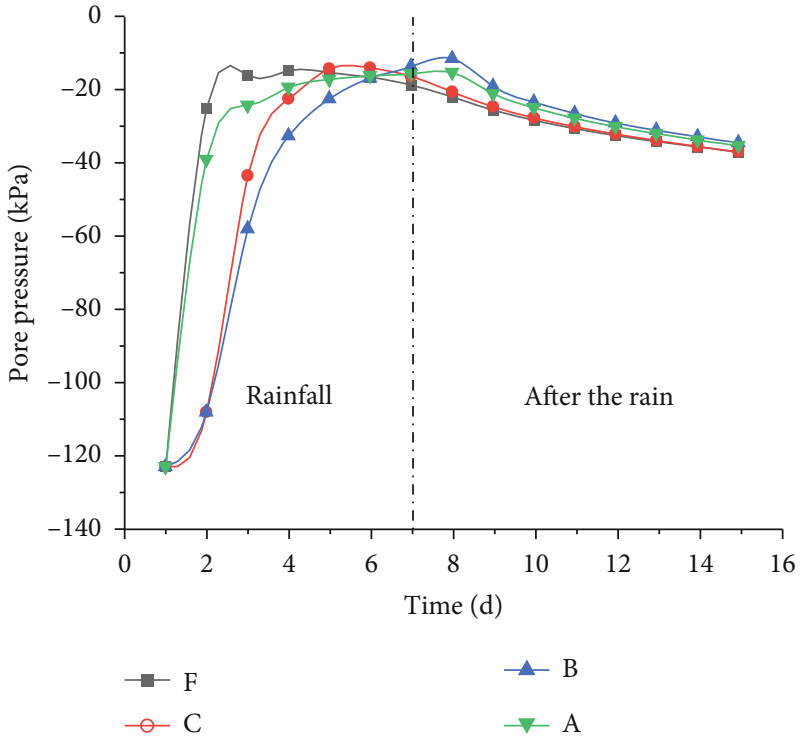

(b) Pore pressure in the middle of the slope

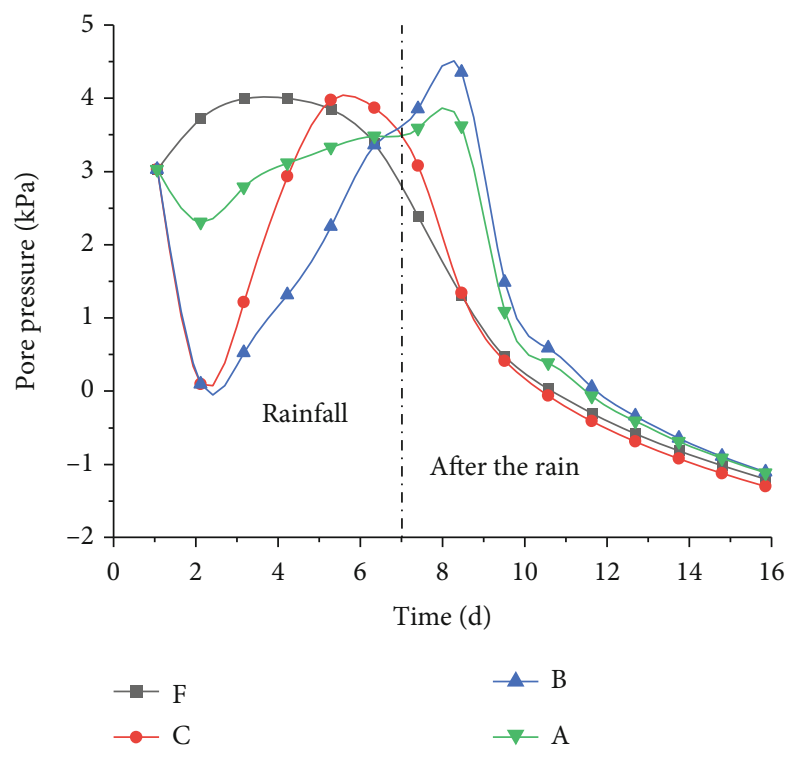

(c) Pore pressure at the toe of the slope

Figure 6: Changes of pore pressure in different rainfall types and the same location.

In general, the safety factors of the four rainfall types from small to large are $\mathrm{F}<\mathrm{A}<\mathrm{B}<\mathrm{C}$, and the minimum safety factor is 1.38. In engineering practice, the front-type rainfall mostly occurs at the end of summer, so the construction unit should avoid the construction at the end of summer, and the slope engineering in use should be well monitored at the end of summer.

4.2.2. Pore Water Pressure. The safety factor is a quantitative description of slope stability. According to the calculation principle of unsaturated soil slope stability described in Section 2, matric suction has an important influence on the shear strength of unsaturated soil. Under the influence of rainfall, the matric suction is mainly related to the pore water pressure. In order to better study the influence of rain- fall on slope stability, monitoring points are arranged at the top, middle, and foot of the slope to explore the changes of pore water pressure in the slope under different rainfall types. The results are shown in Figure 6.

According to Figure 6, the pore water pressure of each monitoring point in the slope increases with the increase of rainfall. After the rain, the pore water pressure decreases with the rain infiltration in the soil and finally tends to be stable. The pore water pressure at the top of the slope reaches a stable value on the fourth day, and the pressure of the slope all reaches a stable value on the sixth day. It can also reflect the process of rainwater seepage and the reaction time of pore water pressure. In addition, it can be seen from Figure 6(c) that under three rainfall conditions, the initial pore water pressure shows a trend of decreasing 


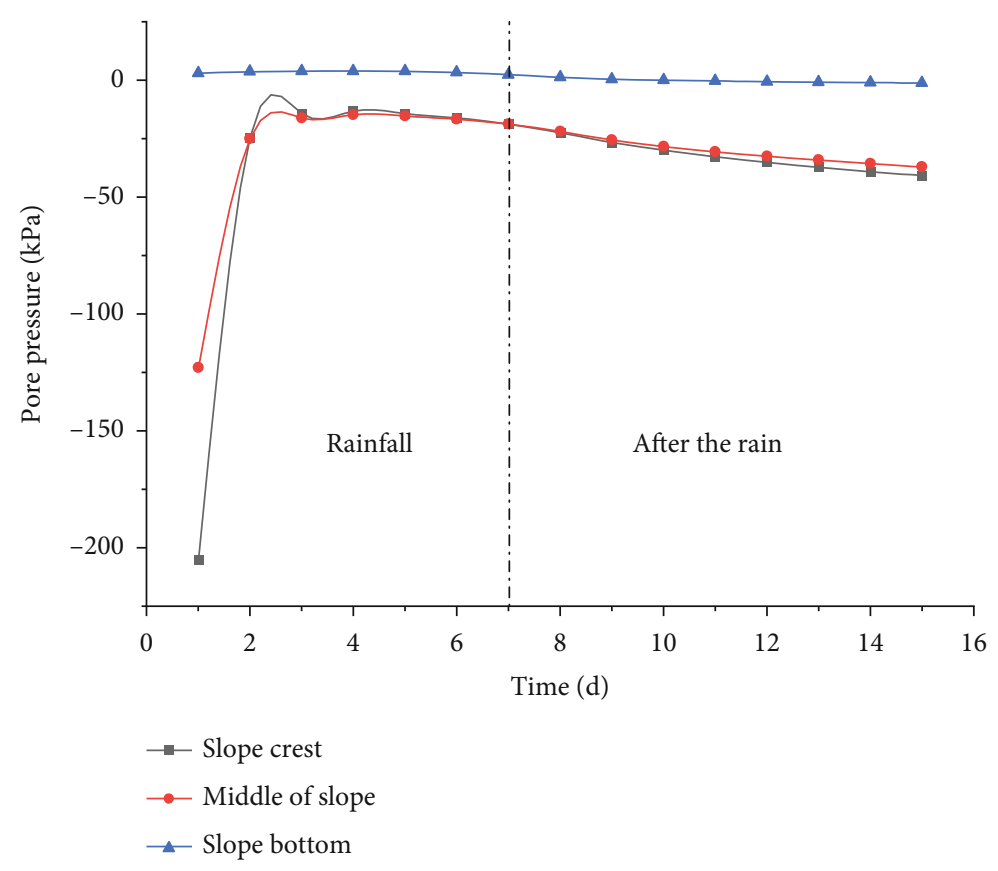

Figure 7: Changes in pore pressure at different locations with the same rainfall type.

first and then rising. This is caused by the rainfall intensity being less than the permeability intensity. The permeability coefficient is assumed to be $20 \mathrm{~mm} / \mathrm{h}(480 \mathrm{~mm} / \mathrm{d})$, but the total rainfall reduction in the initial two days of $\mathrm{C}, \mathrm{B}$, and $A$ is less than the daily infiltration rainfall of the slope, while the pore water pressure starts to rise on the second day. It can be seen that the rainfall intensity and permeability coefficient are not simple linear addition and subtraction to slope stability but a response aging problem. Figure 7 shows the change chart of pore water pressure at each point of the slope under the forward rainfall condition. The change law is consistent with Figure 6. The pore water pressure increases first and then decreases, and the increase and decrease tend to be stable. The pore water pressure in three positions is arranged from small to large: the toe of the slope $<$ the middle of the slope $<$ the top of the slope, but it is worth noting that the pore water pressure at the toe of the slope is basically maintained at about $0 \mathrm{kPa}$. At this time, the matric suction value is the smallest, and the protection measures for the toe should be strengthened. Figure 8 is the pore water pressure cloud chart of the slope under the forward rainfall condition. The representative 2, 5, 8, and 14 days are selected for analysis in the cloud chart of 0-14 days. It can be seen from Figure 8 that the pore water pressure near the slope surface rises rapidly when rainfall occurs, and rainwater penetrates down the slope, and the growth rate of pore water pressure from top to bottom gradually slows down. With the continuous slope saturated with rainfall time, on the 14th day, pore water pressure in the main area of the slope was $0 \mathrm{kPa}$, the matric suction value was the smallest, and the overall stability of the slope was poor.

4.3. Stability Analysis of the Slope with Parameter Interaction. According to the initial values of the saturated permeability coefficient, rainfall intensity, Mohr-Coulomb parameter of material properties, and friction angle, the unsaturated parameter $K_{\mathrm{ms}}$ is 0.018 , rainfall intensity is $20 \mathrm{~mm} / \mathrm{h}$, cohesion $c$ is $15 \mathrm{kPa}$, and internal friction angle $\varphi$ is $30^{\circ}$. The setting ranges of the four parameters are \pm $10 \%, \pm 10 \%, \pm 10 \%$, and $\pm 5 \%$. Based on the Morris quantitative analysis method and statistical principle, there are 15 combinations of the four parameters, as shown in Table 3. Using different parameter combinations and distribution interval values, the slope stability model can be calculated, and the action values of the four input parameters on the slope stability characteristics can be determined.

Under the unsaturated seepage condition, the shear strength parameters of soil which determine the external precipitation of fluid-solid coupling are not independent, and there are interactions among parameters, which change pore pressure, saturation, displacement, and plastic strain which characterize the stability of slopes. The results of finite element simulation based on the Morris input parameter combination can determine the change characteristics of four stability parameters under the action of 15 groups of parameters.

It can be seen from Figure 9(a) that the first four groups $(1,2,3$, and 4$)$ of the 15 groups of parameters are the independent effects of the four parameters, and the abscissa is the standard deviation of the parameters, indicating the coupling interaction between the parameters. The ordinate is the mean value of parameter combination, which indicates the direct effect of parameters on pore pressure characteristics of slope stability. The mean value and standard deviation of $\mathrm{C} 2>\mathrm{C} 1>\mathrm{C} 3>\mathrm{C} 4$; that is, the rainfall intensity has the most obvious effect on the pore pressure characteristics of slope stability. The standard deviation of $\mathrm{C} 6, \mathrm{C} 7, \mathrm{C} 8$, and $\mathrm{C} 9$ is greater than the mean value and standard deviation of $\mathrm{C} 5$; 


\begin{tabular}{|l|}
$\square-200--150 \mathrm{kPa}$ \\
$\square-150--100 \mathrm{kPa}$ \\
$\square-100--50 \mathrm{kPa}$ \\
$\square-50-0 \mathrm{kPa}$ \\
$\square 0-50 \mathrm{kPa}$ \\
$\square 50-100 \mathrm{kPa}$ \\
$\square 100-150 \mathrm{kPa}$ \\
$\square 150-200 \mathrm{kPa}$ \\
$\square 200-250 \mathrm{kPa}$ \\
$\square 250-300 \mathrm{kPa}$ \\
$\square 300-350 \mathrm{kPa}$ \\
$\square 350-400 \mathrm{kPa}$ \\
$\square 400-450 \mathrm{kPa}$ \\
$\square 450-500 \mathrm{kPa}$
\end{tabular}

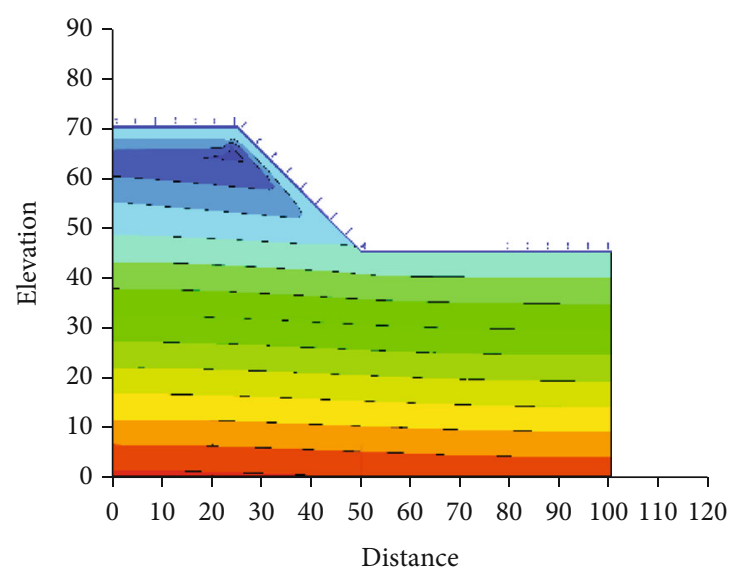

(a) Lasted two days

\begin{tabular}{|l}
$\square-150--100 \mathrm{kPa}$ \\
$\square-100--50 \mathrm{kPa}$ \\
$\square-50-0 \mathrm{kPa}$ \\
$\square 0-50 \mathrm{kPa}$ \\
$\square 50-100 \mathrm{kPa}$ \\
$\square 100-150 \mathrm{kPa}$ \\
$\square 150-200 \mathrm{kPa}$ \\
$\square 200-250 \mathrm{kPa}$ \\
$\square 250-300 \mathrm{kPa}$ \\
$\square 300-350 \mathrm{kPa}$ \\
$\square 350-400 \mathrm{kPa}$ \\
$\square 400-450 \mathrm{kPa}$ \\
$\square 450-500 \mathrm{kPa}$
\end{tabular}

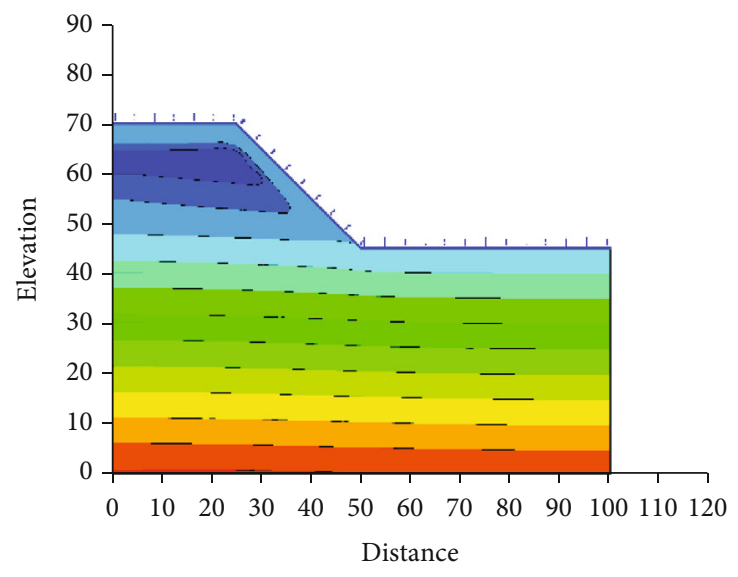

(b) Lasted five days

\begin{tabular}{|l|}
$\square-150--100 \mathrm{kPa}$ \\
$\square-100--50 \mathrm{kPa}$ \\
$\square-50-0 \mathrm{kPa}$ \\
$\square 0-50 \mathrm{kPa}$ \\
$\square 50-100 \mathrm{kPa}$ \\
$\square 100-150 \mathrm{kPa}$ \\
$\square 150-200 \mathrm{kPa}$ \\
$\square 200-250 \mathrm{kPa}$ \\
$\square 250-300 \mathrm{kPa}$ \\
$\square 300-350 \mathrm{kPa}$ \\
$\square 350-400 \mathrm{kPa}$ \\
$\square 400-450 \mathrm{kPa}$ \\
$\square 450-500 \mathrm{kPa}$
\end{tabular}

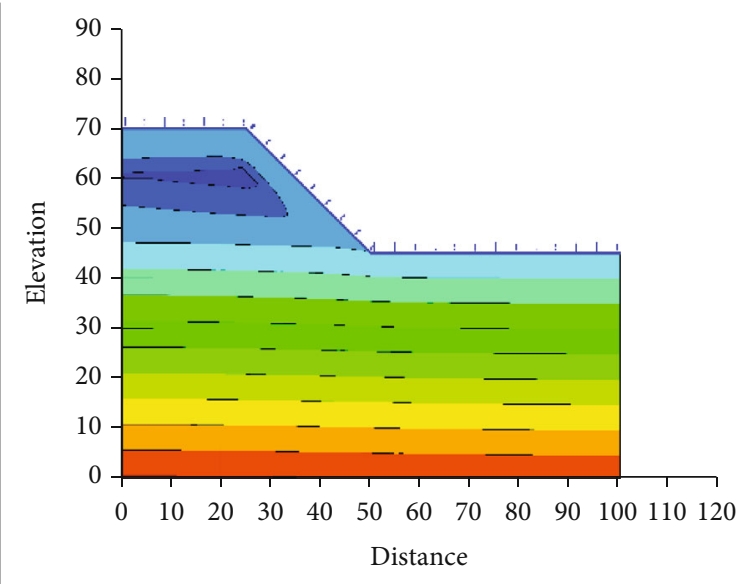

(c) Lasted eight days

Figure 8: Continued. 


\begin{tabular}{|l}
$\square-150--100 \mathrm{kPa}$ \\
$\square-100--50 \mathrm{kPa}$ \\
$\square-50-0 \mathrm{kPa}$ \\
$\square 0-50 \mathrm{kPa}$ \\
$\square 50-100 \mathrm{kPa}$ \\
$\square 100-150 \mathrm{kPa}$ \\
$\square 150-200 \mathrm{kPa}$ \\
$\square 200-250 \mathrm{kPa}$ \\
$\square 250-300 \mathrm{kPa}$ \\
$\square 300-350 \mathrm{kPa}$ \\
$\square 350-400 \mathrm{kPa}$ \\
$\square 400-450 \mathrm{kPa}$ \\
$\square 450-500 \mathrm{kPa}$ \\
$\square$
\end{tabular}

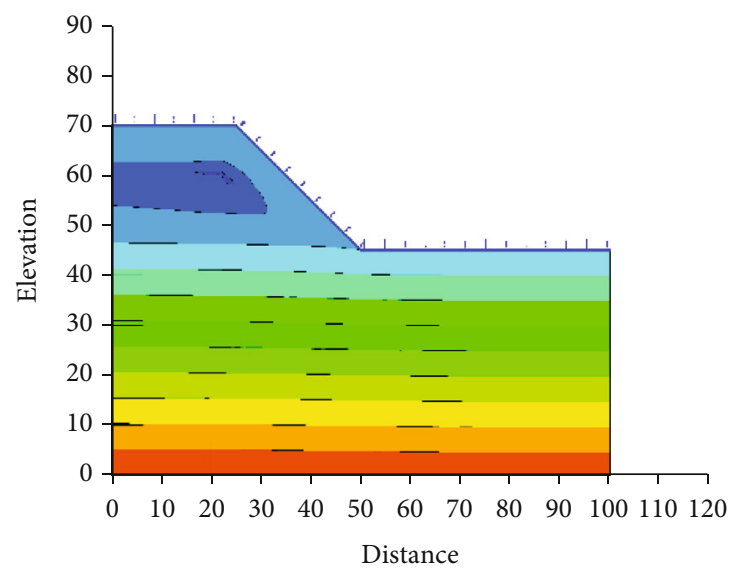

(d) Lasted fourteen days

FIGURE 8: Forward-type pore pressure cloud map.

TABLE 3: Input parameters and fluctuation range.

\begin{tabular}{lccc}
\hline $\begin{array}{l}\text { Parameter } \\
\text { combination }\end{array}$ & $\begin{array}{c}\text { Parameter } \\
\text { item }\end{array}$ & $\begin{array}{c}\text { Parameter } \\
\text { combination }\end{array}$ & $\begin{array}{c}\text { Parameter } \\
\text { item }\end{array}$ \\
\hline C1 & $K_{\mathrm{ms}}$ & $\mathrm{C} 10$ & $c, \varphi$ \\
C2 & $q$ & $\mathrm{C} 11$ & $K_{\mathrm{ms}}, q, c$ \\
C3 & $c$ & $\mathrm{C} 12$ & $K_{\mathrm{ms}}, q, \varphi$ \\
C4 & $\varphi$ & $\mathrm{C} 13$ & $q, c, \varphi$ \\
C5 & $K_{\mathrm{ms}}, q$ & $\mathrm{C} 14$ & $K_{\mathrm{ms}}, c, \varphi$ \\
C6 & $K_{\mathrm{ms}}, c$ & $\mathrm{C} 15$ & $K_{\mathrm{ms}}, q, c, \varphi$ \\
C7 & $K_{\mathrm{ms}}, \varphi$ & & \\
C8 & $q, c$ & & \\
C9 & $q, \varphi$ & & \\
\hline
\end{tabular}

that is, the former parameter combination has a positive effect on the pore pressure characteristics of slope stability, $\mathrm{C} 4$ has a negative effect on the pore pressure characteristics, and the interaction coupling between them reduces the impact on the pore pressure characteristics of slope stability.

It can be seen from Figure 9(b) that the mean value and standard deviation of $\mathrm{C} 2>\mathrm{C} 1>\mathrm{C} 3>\mathrm{C} 4$; that is, the rainfall intensity has the most obvious influence on the pore pressure characteristics of slope stability, and the coupling interaction between rainfall intensity and other three parameters is weak.

The direct effect of the combination of two parameters is shown. The order of parameter combinations from high to low is $\mathrm{C} 6>\mathrm{C} 7>\mathrm{C} 5>\mathrm{C} 10>\mathrm{C} 8>\mathrm{C} 9$, and the smallest two groups of $\mathrm{C} 8$ and $\mathrm{C} 9$ have the same rainfall intensity. Combined with the direct effect of single-parameter analysis, the influence of rainfall intensity on saturation is negative. According to the standard deviation, the coupling effect of parameters from high to low is $\mathrm{C} 8>\mathrm{C} 9>\mathrm{C} 5>\mathrm{C} 10>\mathrm{C} 3$, and the slope stability analysis after reinforcement is C6>C7.

It can be seen from Figure 9(c) that among the direct effects represented by the mean value, $\mathrm{C} 2>\mathrm{C} 4>\mathrm{C} 3>\mathrm{C} 1$, and the standard deviation from large to small is $\mathrm{C} 4>\mathrm{C} 3>\mathrm{C} 2>\mathrm{C} 1$; that is, the coupling effect between the saturation coefficient and the other three terms is the smallest, and the coupling effect between the internal friction angle and the other three terms has the greatest impact on the displacement characteristics of slope stability.

According to the mean distribution of two-parameter combination, C10 $>\mathrm{C} 6>\mathrm{C} 5>\mathrm{C} 8>\mathrm{C} 9>\mathrm{C} 7$. From the mean value of a single parameter, it can be seen that there is a negative coupling effect between the saturated permeability coefficient and the internal friction angle, which leads to the decrease of the direct and coupling effects of C7 on the displacement variation. Under the multiparameter action, the rainfall intensity, cohesion, and friction angle are positively coupled, so the mean value and standard deviation of $\mathrm{C} 13$ are large. When the three factors work together with the saturated permeability coefficient, the direct effect and coupling effect of $\mathrm{C} 15$ on the displacement change are significantly reduced; that is, the saturated permeability coefficient has a negative effect on the displacement change of characteristic points of slope stability.

It can be seen from Figure 9(d) that in terms of the direct effect represented by the mean value, C3>C2 $>\mathrm{C} 4>\mathrm{C} 1$, and the standard deviation is $\mathrm{C} 3>\mathrm{C} 4>\mathrm{C} 1>\mathrm{C} 2$ in turn. It can be seen from the comprehensive mean value and standard deviation coefficient that the saturated permeability coefficient has the weakest influence on the equivalent plastic strain of slope stability.

From the mean value of the two-parameter combination, $\mathrm{C} 6>\mathrm{C} 10>\mathrm{C} 5>\mathrm{C} 8>\mathrm{C} 9>\mathrm{C} 9$, and the standard deviation from high to low is $\mathrm{C} 10>\mathrm{C} 6>\mathrm{C} 8>\mathrm{C} 9>\mathrm{C} 7>\mathrm{C} 5$. From the comprehensive mean value and standard deviation, it can be seen that the combination of the saturated permeability coefficient, internal friction angle, and cohesion has a more significant effect on the plastic strain characteristics of slope stability than other two-parameter combinations, and the cohesion has a positive coupling effect with them. There is a negative relationship between rainfall intensity and other three parameters. 


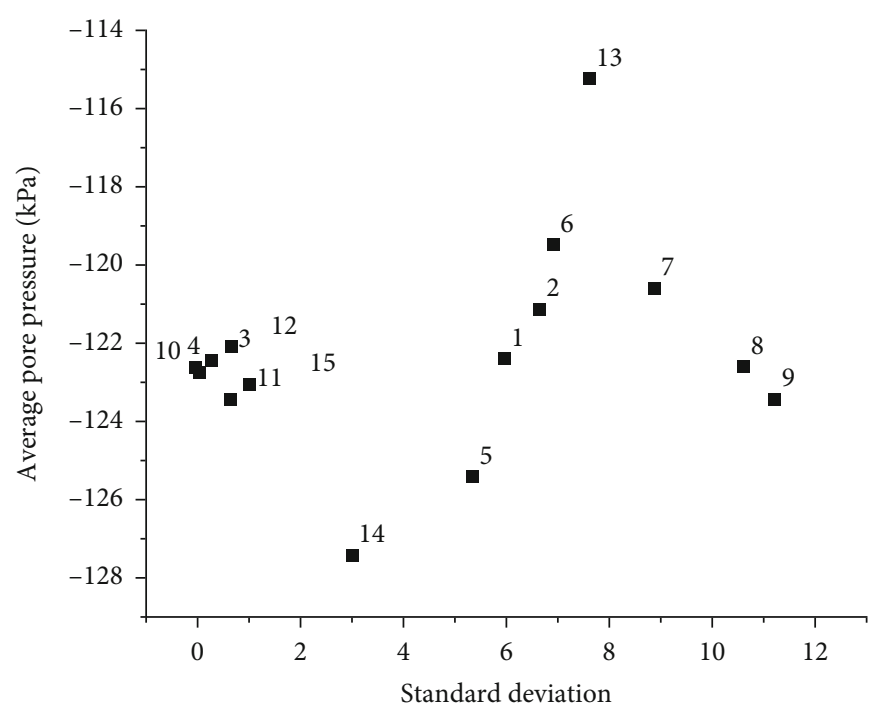

(a) Pore pressure



(b) Saturation

Figure 9: Continued. 


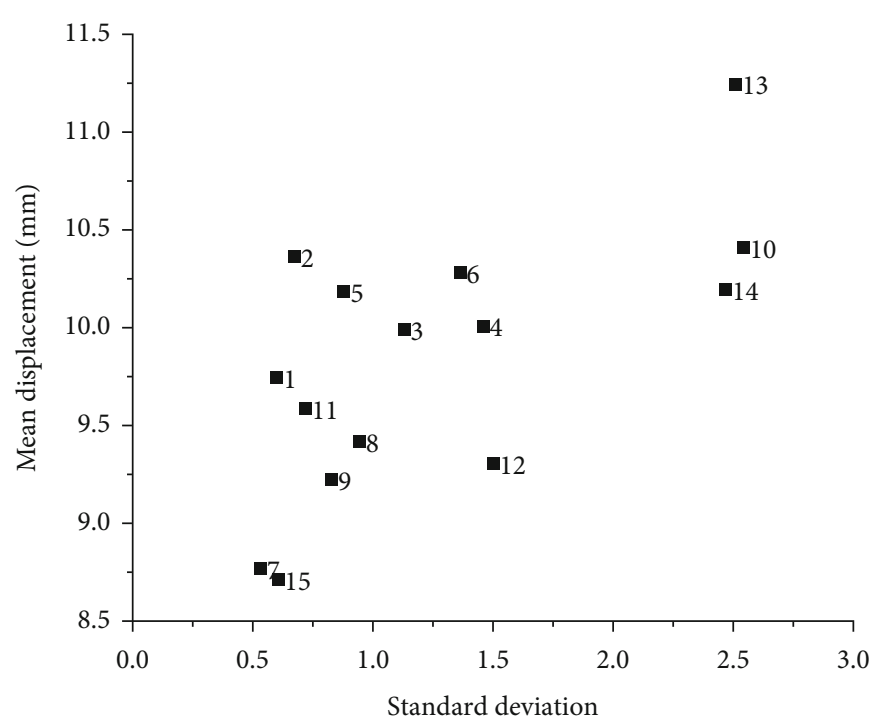

(c) Displacement

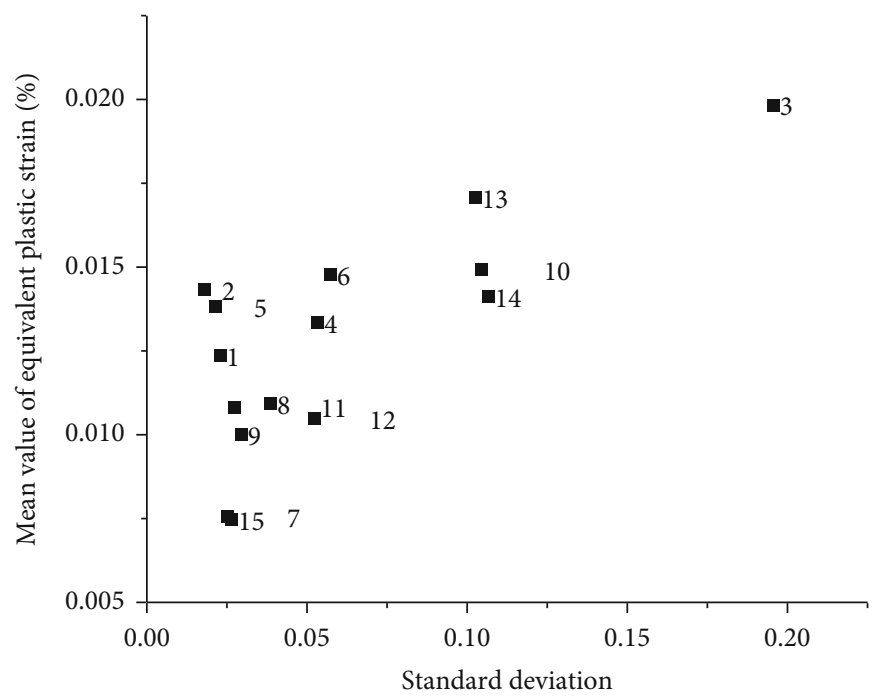

(d) Equivalent plastic strain

Figure 9: Effect of parameter interaction on pore pressure, saturation, displacement, and equivalent plastic strain.

The results show that the direct effect and coupling effect of $\mathrm{C} 15$ are at a small level, which indicates that the interaction coupling effect is not the effect of a single parameter when the four parameters fluctuate together.

\section{Conclusion}

In view of the stability of high and steep slopes under complex conditions, this paper analyzes the stability of slopes in a ski resort under four different rainfall conditions by using GeoStudio finite element analysis software. The coupling analysis is carried out by using the method of parameter combination analysis, and the following conclusions are drawn:

(1) For the same slope, the higher the initial rainfall, the faster the soil saturation speed and the faster the safety coefficient decreases. Different rainfall types have a significant impact on the slope safety coefficient. Qianfeng-type rainfall (the minimum safety factor) occurs at the end of summer, so it is necessary to avoid construction at the end of summer or do safety monitoring at the end of summer

(2) The pore water pressure of each monitoring point increases with the increase of rainfall. At the slope toe, the initial pore water pressure shows a trend of decreasing first and then rising because the rainfall intensity is less than the permeability strength. In addition, the influence of the rainfall intensity and permeability coefficient on slope stability is not simple linear addition and subtraction

(3) For different types of rainfall, the trend and value of the safety factor decrease are basically the same. 
However, considering the timeliness, the impact of different rainfall types on the safety coefficient of the slope is different during rainfall. For the large rainfall, such as the forward type, the sudden drop occurs in the early stage of rainfall, and the latter with small rainfall is slowly decreased in the early stage. This also provides the theoretical basis of time effectiveness for slope support and reinforcement

(4) The direct and coupling effects of the saturated permeability coefficient, cohesion, internal friction angle, and external rainfall intensity on the stability of slopes are at a low level. With the joint changes of the four parameters, the interaction coupling is stacked by algebra with the effect not equal to the single parameter

\section{Data Availability}

The data used to support the findings of this study are included within the article.

\section{Conflicts of Interest}

The authors declare that there is no conflict of interest regarding the publication of this paper.

\section{References}

[1] L. Hao, L. Yi, P. Zhen, T. Xiaojie, and L. Yuanhai, "Analysis on the stability of metro foundation pit under bias pressure from the adjacent slope," Journal of Xi'an University of Architecture \& Technology, vol. 52, no. 3, pp. 359-365, 2020.

[2] L. Yi, Z. Yong, Y. Qing, C. Jiawei, L. Yuanhai, and T. Xiaojie, "Analysis on the stability of bias metro station pit excavated through the combination method of bottom-up and topdown technology," Journal of Xi'an University of Architecture \& Technology, vol. 51, no. 6, pp. 873-881, 2019.

[3] W. Guilin, Y. Yang, S. Fan, and X. Linchuan, "Study on factors affecting the distribution characteristics of slope safety failure probability," Journal of Xi'an University of Architecture \& Technology, vol. 52, no. 4, pp. 463-469, 2020.

[4] C. Y. Liu, Y. Wang, X. M. Hu, Y. L. Han, X. P. Zhang, and L. Z. $\mathrm{Du}$, "Application of GA-BP neural network optimized by grey Verhulst model around settlement prediction of foundation pit," Geofluids, vol. 2021, Article ID 5595277, 16 pages, 2021.

[5] W.-Z. Wa, Q. Xu, Z. H. Guang, L. Jia-Yu, and L. Bo-Yu, "Centrifugal model tests on sliding failure of gentle debris slope under rainfall," Rock and Soil Mechanics, vol. 37, no. 1, pp. 87-95, 2016.

[6] Y. Wu, E. Zhai, X. Zhang, G. Wang, and Y. Lu, "A study on frost heave and thaw settlement of soil subjected to cyclic freeze- thaw conditions based on hydro-thermal-mechanical coupling analysis," Cold Regions Science and Technology, vol. 188, 2021.

[7] T. Hai, K. Lingwei, and L. Bo, "Centrifugal modeling tests on stability of deposits slope under rainfall," Rock and Soil Mechanics, vol. 36, no. 11, pp. 3180-3186, 2015.

[8] X. Zhang, E. Zhai, Y. Wu, D. Sun, and Y. Lu, "Theoretical and numerical analyses on hydro-thermal-salt-mechanical interaction of unsaturated salinized soil subjected to typical unidi- rectional freezing process," International Journal of Geomechanics, vol. 21, no. 7, 2021.

[9] T. Dong, Q. Dong, and J. Shuihua, "Influence of different antecedent rainfall and soil water characteristic curve on slope stability," Journal of Geotechnical Engineering, vol. 37, no. S1, pp. 148-155, 2015.

[10] L. Hongzhou, Y. Yuzhen, and L. Guangxin, "Influence of rainfall characteristics on soil slope failure," Chinese Journal of Rock Mechanics and Engineering, vol. 28, no. 1, pp. 198-204, 2009.

[11] Y. Yang, H. Zhongming, and W. Baolin, "Numerical analysis for seepage characteristics of soil slope with weak intercalations under different rainfall conditions," Mining and Metallurgy Engineering, vol. 3, pp. 15-19, 2018.

[12] Y. Yang and H. Zhongming, "Stability analysis of coarse grained soil high embankment slope under different rainfall conditions," Journal of Changsha University of Science and Technology Natural Science, vol. 14, no. 4, pp. 36-43, 2017.

[13] X. Zhou Jiawen and D. J. Weihua, "Stability analysis of slope under rainfall infiltration," Journal of Water Conservancy, vol. 39, no. 9, pp. 1066-1073, 2008.

[14] X. Quan, T. Xiaohui, and S. Mengfen, "Stability analysis of soil slope under rainfall infiltration," Journal of Geotechnical Engineering, vol. 34, no. S1, pp. 254-259, 2012.

[15] W. Ningwei, Y. Keshun, and L. Jiahao, "Analysis and research on slope stability under different rainfall types," Journal of water conservancy and Construction Engineering, vol. 15, no. 4, pp. 148-152, 2017.

[16] L. Luguang, P. Xiangjun, and H. Runqiu, "Earthquake-triggered landslide occurrence probability in strong seismically mountainous areas: a case study of Jiuzhaigou National Geopark," Chinese Journal of Rock Mechanics and Engineering, vol. 39, no. 10, pp. 2079-2093, 2020.

[17] S. U. Ping, W. A. Gang, L. I. Rongjian et al., "Study on field test of loess slope under the artificial rainfall condition," Journal of Engineering Geology, vol. 27, no. 2, pp. 466-476, 2019.

[18] T. Liang and J. A. Knappett, "Centrifuge modelling of the influence of slope height on the seismic performance of rooted slopes," Géotechnique, vol. 67, 2017.

[19] T. Liang, J. A. Knappett, and N. Duckett, "Modelling the seismic performance of rooted slopes from individual root-soil interaction to global slope behaviour," Géotechnique, vol. 65, no. 12, pp. 995-1009, 2015.

[20] C. Jiangong, L. Hui, and H. Ziyong, "Homogeneous soil slope stability analysis based on variational method," Rock and Soil Mechanics, vol. 40, pp. 2931-2937, 2019.

[21] W. F. Chen, Limit Analysis and Soil Plasticity, Elsevier, Amsterdam, 1975.

[22] C. Y. Han, J. J. Chen, X. H. Xia, and J. H. Wang, "Three-dimensional stability analysis of anisotropic and non-homogeneous slopes using limit analysis," Journal of Central South University, vol. 21, no. 3, pp. 1142-1147, 2014.

[23] C. Xinyu, R. Xuhua, Z. Jixun, and Y. Shuyang, "Study on the influence of different rainfall types on slope stability," Journal of Three Gorges University, vol. 42, no. 2, pp. 34-39, 2020.

[24] N. Hu, J. Du, Y. Y. Ma et al., "Unravelling the role of polyoxovanadates in electrocatalytic water oxidation reaction: active species or precursors," Applied Surface Science, vol. 540, 2021.

[25] K. W. Brhane, M. G. Gebru, and A. G. Ahmad, "Mathematical model for the dynamics of Savanna ecosystem considering fire disturbances," Journal of Theoretical Biology, vol. 509, 2021. 
[26] C. Liu, L. Du, X. Zhang, Y. Wang, X. Hu, and Y. Han, “A New Rock Brittleness Evaluation Method Based on the Complete Stress-Strain Curve," Lithosphere, vol. 2021, no. 4, 2021.

[27] Z. Jianwei, L. Beibei, F. Yalong, Y. Haifeng, and W. Hao, "Study on loading failure characteristics of slope based on transparent soil model test," Journal of Henan University (Natural Science), vol. 50, no. 6, 2020.

[28] C. Yafei and Q. Chunming, "Slope stability analysis under seepage-stress coupling and rainfall infiltratio," Journal of University of South China, vol. 33, p. 43, 2019.

[29] M. Lujiang and S. Jianlong, "Stability analysis and reliabilitystudy of dump slope under rainfall infiltration," Industrial Minerals \& Processing, vol. 48, no. 6, p. 6771, 2019.

[30] A. W. Bishop, "Factors controlling the shear strength of partly saturated soils," in ASCE Res. Conf. Shear Strength of Cohesive Soils, Colorado, 1960.

[31] D. Fredlund, G. Morgenstern, and R. A. Widger, "The shear strength of unsaturated soils," Canadian Geotechnical Journal, vol. 15, no. 3, pp. 313-321, 1978.

[32] S. K. Vanapalli, D. G. Fredlund, D. E. Pufahl, and A. W. Clifton, "Model for the prediction of shear strength with respect to soil suction," Canadian Geotechnical Journal, vol. 33, no. 3, pp. 379-392, 1996.

[33] S. K. Vanapalli, D. G. Fredlund, and D. E. Pufahl, "The influence of soil structure and stress history on the soil-water characteristics of a compacted till," Géotechnique, vol. 49, no. 2, pp. 143-159, 1999.

[34] M. D. Morris, "Factorial sampling plans for preliminary computational experiments," Technometrics, vol. 33, no. 2, pp. 161-174, 1991.

[35] G. Jinxin and S. Yong, "Slope stability analysis based on interaction of unsaturated parameters," Science Technology and Engineering, vol. 21, no. 12, pp. 5076-5083, 2021. 